\title{
THE ESTIMATION OF BLOOD PRESSURE IN CHILDHOOD WITH SPECIAL REFERENCE TO THE CHOICE OF STANDARD CUFFS
}

\author{
BY \\ H. SAINSBURY \\ From the Herefordshire Child Health Centre, Hereford
}

(RECEIVED FOR PUBLICATION APRIL 7, 1953)

In adults the sphygmomanometer gives blood pressure readings similar to those obtained directly with a canula in the artery (Steele, 1942) provided that the inflatable cuff used is of suitable dimensions, i.e., $12 \mathrm{~cm}$. broad (von Recklinghausen, 1901). Smaller cuffs yield high readings (Gumprecht, 1900; Janeway, 1909; Phipps, 1915; Day, 1939) especially in high tension pulses (Hutchison and Rainy, 1924) and broader cuffs may give low readings (Cook, 1903; Robinow, Hamilton, Woodbury and Vopitto, 1939). The length of the cuff in relation to the circumference of the arm is a matter on which opinions have differed and is probably of much less significance. In view of the wide variation in the size of children's arms difficulty has been experienced in obtaining agreement on the most suitable dimensions for standard children's cuffs. Nicholson (1915) recommended for children of 4 to 8 years a cuff $9 \mathrm{~cm}$. broad and for children 8 to 15 years one $13 \mathrm{~cm}$. Robinow et al. (1939) recommend a cuff $2.5 \mathrm{~cm}$. broad for the newborn, $5 \mathrm{~cm}$. for small children, and $9 \mathrm{~cm}$. for older children. The American Heart Association (1951) recommends cuffs 8-9 cm. for older children under 9 years, $5-6 \mathrm{~cm}$. for children under 4 years, and for infants under 1 year $2.5 \mathrm{~cm}$. Taussig (1940) suggests that the breadth of the cuff should be two-thirds the length of the upper arm. This appears to be generally accepted by paediatricians in Britain.

Although certain writers (Day, 1939; AllenWilliams, 1945) have folded the rubber bag within the cuff in such a way as to adjust its breadth to the size of the arm, the method is not convenient in clinical practice where it is usual to employ cuffs of standard sizes. In this country there are available three standard sizes of cuff, namely 1 in. $(2 \cdot 5 \mathrm{~cm}$.), 2 in. $(5.0 \mathrm{~cm}$.) and $4 \mathrm{in}$. $(10 \mathrm{~cm}$.) in breadth. The adult cuff measures 5 in. $(12 \cdot 5 \mathrm{~cm}$.).* It is the

- Other cuffs, e.g., 7, 9.5 and $12 \mathrm{~cm} .$, are also available [ED.]. purpose of this paper to ascertain how far these cuffs may be employed to obtain comparable blood pressure readings.

The dimensions of these cuffs were no doubt originally based on experiment, but appear now to be determined by demand, and no information could be obtained from the instrument makers concerning the ages for which they are intended.

It is more convenient to refer to the size of children in terms of age, and for this purpose mean values for the length of the upper arms of children at different ages were obtained and are presented in Table 1. The measurements were taken from the fold of the axilla to the centre of the antecubital space with the arm semiflexed and the forearm supinated.

In Fig. 1 the histogram represents the length of arm which should be enclosed by the cuff, i.e., twothirds of the mean arm lengths in Table 1 , to give blood pressures comparable at one age with another. The breadths of the $5 \mathrm{~cm}$., $10 \mathrm{~cm}$., and adult cuffs

TABLE 1

AVERAGE MEASUREMENTS OF UPPER ARM OF CHILDREN AGED 1-17 YEARS*

\begin{tabular}{|c|c|c|c|}
\hline $\begin{array}{l}\text { Age of } \\
\text { Child }\end{array}$ & $\begin{array}{l}\text { Mean Arm } \\
\text { Length (cm.) }\end{array}$ & $\begin{array}{l}\text { Range of } \\
\text { Values (cm.) }\end{array}$ & $\begin{array}{l}\text { Variability } \\
\text { (S.D.) }\end{array}$ \\
\hline 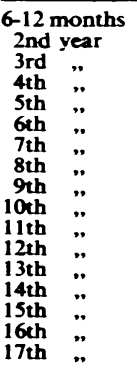 & $\begin{array}{r}6 \cdot 5 \\
9 \cdot 3 \\
10 \cdot 5 \\
11 \cdot 4 \\
12 \cdot 5 \\
13 \cdot 0 \\
14 \cdot 0 \\
14 \cdot 0 \\
14 \cdot 5 \\
14 \cdot 8 \\
15 \cdot 0 \\
16 \cdot 0 \\
17 \cdot 0 \\
17 \cdot 5 \\
18 \cdot 5 \\
19 \cdot 0 \\
19 \cdot 1\end{array}$ & $\begin{array}{c}7-5 \cdot 5 \\
9-10 \\
9-13 \\
9 \cdot 5-13 \\
10-15 \\
11-16 \\
12-16 \cdot 5 \\
12-15 \cdot 5 \\
12 \cdot 5-17 \\
13-17 \\
14 \cdot 5-19 \\
14 \cdot 5-18 \\
14-19 \\
15-20 \\
16-24 \\
15-22 \\
16-24\end{array}$ & $\begin{array}{l}0 \cdot 8 \\
0 \cdot 8 \\
0 \cdot 8 \\
0 \cdot 7 \\
1 \cdot 0 \\
1 \cdot 25 \\
1 \cdot 2 \\
1 \cdot 0 \\
1 \cdot 3 \\
1 \cdot 4 \\
1 \cdot 25 \\
1 \cdot 06 \\
1 \cdot 3 \\
1 \cdot 3 \\
1 \cdot 37 \\
1 \cdot 5 \\
1 \cdot 7\end{array}$ \\
\hline
\end{tabular}

- Derived from samples of 20 boys and 20 girls in each age group. 
(shown as shaded areas) are superimposed to emphasize the differences between the required breadth and that of the standard cuff which most nearly approximates to it. Where alternative standard cuffs exist the larger has been shown. It will be seen that a material discrepancy occurs in the age intervals 2-6 years and 12-13 years.

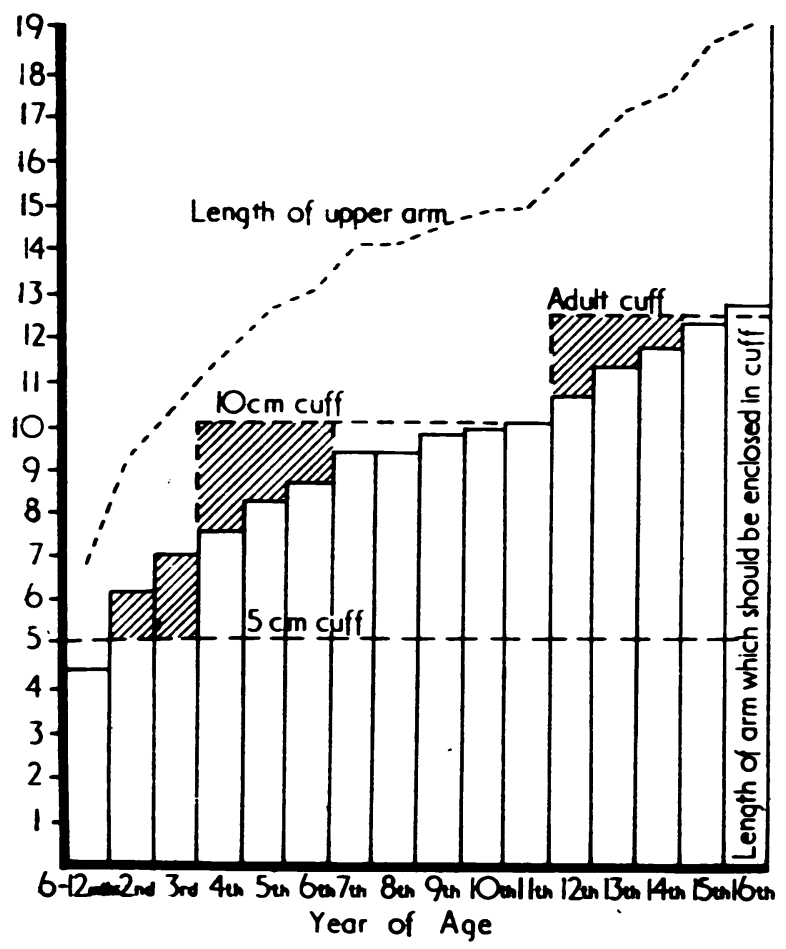

Fig. 1.-Illustration of the extent to which standard cuffs are applicable to the arms of children aged 1-16 years.

The effect of these discrepancies on blood pressure readings was examined by subjecting samples of children to examination using both the standard cuff and one folded to enclose exactly two-thirds of the arm. Mean differences between the pairs of readings are shown in Table 2.

The children were examined in accordance with the recommendations of the Cardiac Society of Great Britain and the American Heart Association (1939). The instrument used was a standard type of mercurial manometer. The cuff was folded in the manner described by Day (1939). Each examination consisted of a series of readings taken alternatively with the standard and folded cuff until they became relatively constant.

The size of the samples was governed by the
TABLE 2

DISCREPANCIES BETWEEN PAIRS OF READINGS OBTAINED WITH A STANDARD CUFF AND ONE TWO THIRDS THE LENGTH OF THE ARM AT CERTAIN AGE INTERVALS

\begin{tabular}{|c|c|c|c|c|c|}
\hline $\begin{array}{l}\text { Size of standard cuff } \\
\text { (cm.) }\end{array}$ & 5 & & 10 & & $12 \cdot 5$ \\
\hline $\begin{array}{l}\text { Size of folded cuff } \\
\text { (cm.) }\end{array}$ & 7 & $7 \cdot 5$ & 8 & $8 \cdot 5$ & 11 \\
\hline $\begin{array}{l}\text { Length of upper arm } \\
\text { (cm) }\end{array}$ & 10 & 11 & 12 & 13 & $16-17 \cdot 5$ \\
\hline Age of children (Grs.) & 2 and 3 & 4 & 5 & 6 & $12-14$ \\
\hline $\begin{array}{l}\text { No. of children ex- } \\
\text { amined .. }\end{array}$ & 50 & 33 & 33 & 34 & 56 \\
\hline $\begin{array}{l}\text { Systolic Readings } \\
\text { Range of pressures } \\
\text { (mm. Hg) } \\
\text { Meai difierence be- } \\
\text { tween readings } \\
\text { (mm. Hg) } \\
\text { Range of differences } \\
\text { (mm. Hg) } \\
\text { Standard error }( \pm \text { ) }\end{array}$ & $\begin{array}{c}80-120 \\
8 \\
0-16 \\
0.5\end{array}$ & $\begin{array}{c}7 \\
1-12 \\
0 \cdot 5\end{array}$ & $\begin{array}{c}80-135 \\
5.4 \\
0-15 \\
0.6\end{array}$ & $\begin{array}{c}80-135 \\
4 \cdot 7 \\
0-20 \\
0 \cdot 4\end{array}$ & $\begin{array}{c}92-145 \\
3 \cdot 3 \\
0-15 \\
0.3\end{array}$ \\
\hline $\begin{array}{l}\text { Diastalic Readings } \\
\text { Range of pressures } \\
\text { (mm. Hg) } \\
\text { Mean differences be- } \\
\text { twreen readings } \\
\text { (mm. Hg) } \\
\text { Range of difierences } \\
\text { (mm. Hg) } \\
\text { Standard error }(=)\end{array}$ & $\begin{array}{c}6 \\
0-20 \\
0.42\end{array}$ & $\begin{array}{c}7 \\
0-20 \\
0.57\end{array}$ & $\begin{array}{l}4 \cdot 8 \\
0-15 \\
1 \cdot 0\end{array}$ & $\begin{array}{c}40-90 \\
4 \\
\\
0-20 \\
0.6\end{array}$ & $\begin{array}{r}55-95 \\
5 \\
0-10 \\
0.6\end{array}$ \\
\hline
\end{tabular}

variability of the differences between the pairs of readings to yield a standard error of 1 or less.

\section{Conclusions}

It will be seen in Fig. 1 that the $10 \mathrm{~cm}$. cuff can be applied to the arm of all children over the age of 3 years, but it particularly approximates to the required dimensions between the ages of 7 and 11 years. Between 4 and 6 years the cuff is some$v$ hat large and gives readings on an average 4.7 $\mathrm{mm}$. $\mathrm{Hg}$ (according to age) lower than those c btained with a cuff strictly proportional to the lingth of the arm. Similarly in the twelfth and $t$ irteenth years the cuff is small and readings higher $t$ lan they should be.

Although strictly speaking the adult cuff should $t$ e reserved for children of 15 years and over, it may $\checkmark$ ith advantage be employed to obtain more stable $r$ sults in the age periods of 12 years and over. In tire twelfth and thirteenth years systolic readings c btained with this cuff are low by $3 \cdot 3 \mathrm{~mm}$. $\mathrm{Hg}$.

Below the age of 4 years only the smallest cuff will fit the arm but at three years this cuff is somewhat small and readings are found to be $8 \mathrm{~mm}$. $\mathrm{Hg}$ systolic and $6 \mathrm{~mm}$. diastolic higher than those obtained with a cuff exactly two-thirds of the arm length.

Individual differences between pairs of readings 
varied within $20 \mathrm{~mm} . \mathrm{Hg}$, and this should be viewed against the usual range of normality. Pairs of high readings showed no obvious tendency to greater discrepancy than did lower readings throughout the range of pressures observed.

\section{Summary}

An attempt has been made to ascertain to what extent the standard sizes of inflatable cuffs normally available are applicable to children of different ages, presuming that to obtain comparable readings they should enclose two-thirds of the upper arm of the children for whom they are intended.

Mean values for the size of children's arms at different ages are presented, and it was found that the $10 \mathrm{~cm}$. cuff can be used for all children between 4 and 12 years. Below 4 years only the $5 \mathrm{~cm}$. cuff will fit, but children over 12 years can take the adult cuff.

In those age ranges in which these cuffs departed materially from the requirement of enclosing twothirds of the upper arm readings taken with the standard cuff and with a cuff folded to comply with this requirement were compared. The discrepancies, while they varied in individual cases from 0 to $20 \mathrm{~mm}$. $\mathrm{Hg}$, were generally small.

I wish to thank Dr. Cookson, County Medical Officer, and Dr. Hugh Fisher, Consultant Paediatrician to the Herefordshire Child Health Centre, for permission to publish this paper and for their helpful suggestions in its preparation; also Mr. Gordon Cossor, of A. C. Cossor Ltd. for information concerning the manufacture and supply of the cuffs.

\section{REFERENCES}

Allen-Williams, G. M. (1945). Archives of Disease in Childhood, 20, 125.

American Heart Association (1951). Circulation, N.Y., 4. 503

Cardiac Society of Gt. Britain and American Heart Association (1939). Reported in Brit. med. J.. 2. 184.

Cook, H. W. (1903) Amer. J. med. Sci., 125, 433.

Cossor, G. Personal communication.

Day, R. (1939). J. Pediat., 14, 382.

Hutchison, R. and Rainy, H. (1924). Clinical Methods, 8th ed. p. 192. London.

Taussig, H. B. (1940). In Holt's Diseases of Infancy and Childhood 11th ed., p. 557. New York.

Janeway, T. C. (1909). Arch. intern. Med., 3. 474

Nicholson, P. (1915). Blood Pressure in General Practice, 3rd ed. p. 134. London.

Phipps, C. (1915). Boston med. surg. J., 173. 476

Recklinghausen, H. von (1901). Arch. exp. Path. Pharmak., 46, 78.

Robinow, M., Hamilton, W. F., Woodbury, R. A. and Vopitto, P. P. (1939). Amer. J. Dis. Child.. 58. 102

Steele, J. M. (1942). J. Mt Sinai Hosp., 8. 1042 